\title{
The Courtyer of Count Baldasser Castilio: Italian Manners and the English Court in the Sixteenth Century
}

\section{Kenneth R. Bartlett}

Some short time before the beginning of March 1561 William Seres, printer, at the Sign of the Hedgehog in St. Paul's Churchyard, received a licence to print "a boke called Curtysse," a book which the translator had carefully seen through the press in person during the previous months. ${ }^{1}$ This title was, of course, Il Cortegiano of Baldassare Castiglione, translated by Thomas Hoby as The Courtyer of Count Baldassar Castilio.

Much has been made of this moment. Indeed, it has been identified as a watershed in the development of the character of the English Renaissance courtly mentalité. One historian has proclaimed that "The vogue for Italian manners ushered in by Hoby's translation led numbers of young Englishmen to undertake a grand tour of the Italian states to gain firsthand experience of a society that would be a passport to the court on their return." 2 Another, Walter Raleigh, in the introduction to his 1900 edition of Hoby's translation, writes: "The Courtier crossed the channel and became an Englishman. The translation was a pioneer of Italian studies in England; his book, reprinted again and again, became one of the most influential books of the ensuing age, the age of Shakespeare, and Spenser, and Sidney." ${ }^{3}$

Still another observed that, "Hoby's translation had a marked influence upon English life and customs, bringing, as it did, to England not only Italian classicism but Italian culture as well." 4 And, finally, it has been stated that the book in England enjoyed an "influence on Elizabethan taste and manners (that) can hardly be exaggerated." ${ }^{5}$ This is the received opinion of scholars and one re-inforced by the large number of editions of Castiglione that appeared during the Sixteenth Century. ${ }^{6}$ The question arises, however, of why Hoby's translation of Il Cortegiano was so popular 
and why it found such a receptive climate in England after 1561. Why and how did Castiglione become the new exemplar of English courtly practice?

It first must be established that Hoby's contemporaries identified the significance of the book. Roger Ascham in the first book of The Scholemaster, written in 1563-4, just two years after the publication of The Courtier, remarked: "To join learning with comely exercises, Conto Baldassare Castiglione, in his book Cortegiano, doth trimly teach, which book, advisedly read and diligently followed but one year at home in England should do a young gentleman more good, I wis, than three years' travel abroad spent in Italy. And I marvel this book is no more read in the court that it is, seeing it is so well translated into English by a worthy gentleman, Sir Thomas Hoby, who was many ways well furnished with learning and very expert in knowledge of divers tongues."7 Ascham then continues, of course, to vilify the Italianate Englishman at some length, a prejudice that helps to explain his insistence on learning one's Castiglione at home in England. ${ }^{8}$ Nevertheless, a strongly positive testimonial from such a hostile observer is, if anything, more impressive.

Some time later, as reported by Pierce in his Superogration, the image of Castiglione's perfect knight had become an ideal standard and a comparison of high praise. He wrote about Elizabeth's cousin, John Ashley, the author of The Art of Riding, a celebrated treatise on horsemanship, that he dares entitle him, "our English Xenophone; and marvel not that Pietro Bizzarro, a learned Italian, proposeth him for a perfect pattern of Castilio's courtier." 9 The point is clear: to approach the level of personal accomplishment described by Castiglione is to have reached a laudable pinnacle of human achievement - even among insular little Englanders like Ascham.

But again, can we attribute this remarkable alteration in the aristocratic English mentality only to the power of one book, however brilliant? And, must we identify the beginnings of this Italianate predilection with the reign of Elizabeth, whose accession occurred less than three years before the publication of Hoby's translation? The response is evidently no: English attitudes towards artistocratic, courtly behaviour had been changing gradually but significantly from at least the beginning of the century, so that by the time Hoby's version of Il Cortegiano was available in English, there was a natural, prepared, ready market for it, com- 
posed of well-born, young gentlemen eager for a new model of polished, social behaviour.

During the fifteenth century, the image of the English courtier remained essentially feudal, looking back towards Malory, whom Ascham identified with bloody murder and bold bawdry. ${ }^{10} \mathrm{Al}-$ though there had been particular attempts to introduce Italianate ideals into England by men such as Duke Humphrey of Gloucester $^{11}$ and later by that most perfect example of un diavolo incarnato, John Tiptoft, Earl of Worcester, ${ }^{12}$ who, before his execution, had been profiled by Vespasiano and learned his martial, courtly and literary arts on the peninsula itself, these efforts were stillborn. The culture and attitudes of Quattrocento Italy never adhered firmly to the alien surface of that island outpost, mired as it was in civil war and desolation, and dominated still by the ideals and practice of a resurgent, if bastard, feudalism.

Also, the intellectual traditions of the fifteenth century were clerical or collegiate. Exceptional individuals, such as John Free, Robert Flemmyng, and John Gunthorpe ${ }^{13}$ — all of whom had studied in Italy - acquired great personal erudition and nourished humanist libraries; but they were not courtiers as much as ecclesiastics and scholars. Similarly, the great generation of the turn of the sixteenth century that produced the first self-sustaining links to the peninsula made connections with Italian universities and with men of learning, not with noble gentlemen, polished to decorate courts. This coterie, comprised of luminaries like Thomas Linacre, William Grocyn, William Latimer, Cuthbert Tunstall and Richard Pace, ${ }^{14}$ made humanist Italian culture available in England through their tuition and connections; but only in the last example of Pace do we see the beginnings of a new ideal of aristocratic courtly behaviour cultivated and promoted.

Richard Pace began as had his fellows. He was sent to study Litterae Humaniores by his clerical patron Bishop Langton of Worcester. Pace, friend and confidant of More, Colet and Erasmus, saw the distinctions between the ideals of aristocratic behaviour elucidated by Italian educators, such as Vittorino da Feltre and Guarino of Verona, and those practiced by his noble countrymen, too many of whom were addicted to the anti-intellectual traditions of feudal thuggery. In his 1517 De Fructu Qui Ex Doctrina Percipitur, Pace burlesques this contrast: "God damn it," a somewhat inebriated nobleman announces at dinner, "I'd rather see my son hanged than be a student. Sons of the nobility ought to blow the horn properly, hunt like experts and train and carry a 
hawk gracefully. Studies, by God, ought to be left to country boys." To which Pace - in an obvious example of ésprit de l'escalier - replies: "I don't think you're right, my good man. For if some foreigner came to the King, a royal ambassador, for example, and he had to be given an answer, your son, brought up as you suggest, would only blow his horn, and the learned country boys would be called on to answer him. They would obviously be preferred to your son, the hunter or hawker." 15 Pace is clearly advocating a more humane model of courtly, aristocratic behaviour, certainly influenced by his humanist studies at Padua and Bologna and by his constant employment as a diplomat at the courts and council chambers of Italy. Doubtlessly, Pace's advice was a humanist commonplace; but for our purposes it is instructive because it is levelled directly at the model of the English courtier prevalent during the fifteenth and the early years of the sixteenth centuries, the world of John Skelton. And Pace, it should be noted, was writing at the same time as Castiglione. The traditions exemplified in Castiglione were thus being established in England, but the monument to them was yet to appear in print.

In addition, of course, it must be remembered that Castiglione himself had been in England, visiting the court of Henry VII in late 1506 to accept the Order of the Garter for his master Duke Guidobaldo of Urbino. It would be difficult, however, to make much of this historic and portentous moment. Castiglione's embassy was brief and his contacts limited. Although Italian Renaissance humanist values were being slowly established at the English court just before and during the period of Castiglione's visit, the effects of these initiatives had no connection with the presence of Castiglione in England. The offices of Latin Secretary (held by such Italian scholars as Polydore Vergil and Andrea Ammonio), the royal librarianship and the temporary appointment at court of individual Italian letter writers in the new style, such as Pietro Carmeliano, had made the ideals of Italian Renaissance culture available to those surrounding King Henry VII. Nevertheless, Castiglione's residence in England in that autumn of 1506 should be seen only as part of the literary frame of il Cortegiano - Castiglione places the action in Urbino while he himself was engaged in this embassy - and as a prefiguration of future developments, not as a critical point of contact between the Montefeltro court of Urbino and the Tudor Court of England. ${ }^{16}$

The generation immediately before Hoby's re-inforced the growing tendency to connect an Italian education and Italianate 
manners with success as a courtier. The household that surrounded Reginald Pole, the cousin of King Henry VIII, was quite different from the previous groups of English scholars in Italy. ${ }^{17}$ Pole has been recommended to the Studio di Padova by his Oxford tutor William Latimer and thereby sustained a continuing link between the English and Italian universities that characterized the rest of the century, and indeed, confirmed the connection between the two nations that existed until our own time. ${ }^{18}$ To this rich, young layman of royal blood were attracted secular scholars not intent on Church or even University careers but on careers at court as functionaries of that professional Tudor civil service erected by Thomas Cromwell: men such as Sir Richard Morison, a Padua trained civilian, who introduced Machiavelli's principles into the vocabulary of English political thought; and Thomas Starkey, whose Dialogue Between Pole and Lupset advocates an elective monarchy modelled on the Venetian republic and argues, as did Tiptoft the century before, that Roman Civil Law should be introduced into England to replace Common Law. ${ }^{19}$

These lay humanists of the lesser gentry were summoned to court by Cromwell to become royal servants, fulfilling Pace's prophecies. The one, Morison, succeeded, growing rich and powerful under Edward VI while the other, Starkey, died in disgrace because he failed to ensure Pole's allegiance to his cousin and the Henrician reform.

Also, the examples of other prominent young Italianate courtiers made the growing interest in Italian social, cultural, educational and military ideals visible to all who frequented the avenues of power. There was Sir Thomas Wyatt the Elder who made the first direct translations - of Petrarch and Aretino - from Italian into English since Chaucer; ${ }^{20}$ Sir John Russell, later first Earl of Bedford, whose Italianate sympathies stemmed from his residence there in the 1520's; Sir Thomas Smith, first regius Professor of Civil Law at Cambridge, who brought a D.C.L. from Padua to court and the University. ${ }^{21}$

Furthermore, Archbishop Cranmer brought learned Italian Protestants to England, in part to offer them refuge for their confessional allegiances, and in part to assist in the reconstruction of the English Church: men like Pietro Bizzarri, already mentioned above, who began as a fellow of St. John's College, Cambridge, and ended as a poet and courtier attached to John Russell's son Francis, himself a celebrated Italophile. And, Bernardino Ochino, Emmanuele Tremelli, Peter Martyr Vermigli, and their fellows, of- 
ten preaching in Michelangelo Florio's Italian Church in London, showed pious young English gentlemen that adhesion to Italian cultural, social and intellectual models need not lead them into apostasy and to Rome. ${ }^{22}$

Finally, the first two great English books on Italy, William Thomas' History of Italy (1549) and his Italian Grammar (1550), written by an important Edwardian courtier with close access to Northumberland and the young King, made the peninsula accessible to well-born and well-educated young gentlemen. For the first time, a literate, polished, accurate entrée into Italian civilisation was available in English, free from the piety, marvels and simple nonsense of pilgrims' guides, Medieval travel accounts and such earlier material. The frame of reference of Castiglione's Cortegiano was therefore no longer completely alien to an English audience and even the book itself could be read in the original by those familiar with the Italian language which was increasingly available in England, taught by resident Italian instructurs and aided by Thomas' Grammar. ${ }^{23}$

It was in this context that Thomas Hoby began his translation of Il Cortegiano. Hoby came of a moderately positioned gentry family of Hertfordshire, ambitious for status and success. He matriculated at St. John's College, Cambridge, the College of Sir Thomas Wyatt and Ascham (remember he, too, was a visitor to Italy, but an unhappy one), the College where Pietro Bizzarri was a fellow and from which Hoby's Cambridge contemporary, Francis Russell, brought him to court. And Tremelli held the Chair of Hebrew at the University.

Before he took a degree, Hoby followed his elder brother, Sir Philip, to the Continent, travelling eventually in 1549 to Padua where he lived and studied for some time, as well as visiting virtually all of the peninsula, returning to England only in $1551 .^{24}$ During those two years in Italy Hoby acquired not only a knowledge of the language but also an appreciation of the culture of mid-sixteenth century Renaissance Italy.

The actual occasion of Hoby's translation is perfect for a disciple of Castiglione. He began his work at the request of a noble lady, in fact, the Marchioness of Northampton, the wife of the lord whose service he had entered. Hoby wrote in the spring of 1552, "I returned again to London the 26th of April, after I had been rid of mine ague; where I prepared myself to go into France and there to apply my book for a season. . . . After I had conveyed my stuff to Paris and settled myself there, the first thing I did was to trans- 
late into English the third book of the Courtier, which my Lady Marquess had often willed me to do and from lack of time ever deferred it." ${ }^{25}$ This, then, was the genesis of the translation.

The accession of Mary in 1553 required Hoby to go abroad again for his safety, as part of the Marian diaspora. And where should a convinced Italophile go but back to Italy, arriving in Padua on 23 August $1554 .^{26}$ Significantly, among the considerable English community already there was John Ashley, Elizabeth's cousin, the very one whom Bizzarri, a mutual friend, would later identify as an English Castiglione; there was John Tamworth, to whom William Thomas had dedicated his Italian Grammar; ${ }^{27}$ and en route Hoby encountered Sir Thomas Wyatt the Younger who had inherited his father's predilection for Italy. ${ }^{28}$ Clearly, the roots of Hoby's interest in Italian culture branched widely, connecting him to the other italianati of pre-Elizabethan England.

It was in Padua that Hoby completed his translation, in the midst of a colony of inglesi italianati, studying together, travelling together and establishing a deep and disciplined familiarity with the civilisation that Castiglione evoked and idealized. The translation, Hoby tells us, was finished finally on the ninth of February $1555 .^{29}$ Thus, the English version of Il Cortegiano was written not at all in England but in France and Italy, particularly the latter, as is quite suitable. While on the peninsula, Hoby cultivated those very arts so brilliantly delineated by Castiglione, and the translator obviously became something of a model of such behaviour himself, given his popularity, his short but stellar career under Elizabeth and his continuing interest in those knightly ideals which he himself came to embody. ${ }^{30}$

The intent, moreover, of Hoby's translation superseded the simple wish of a devotee to build a monument to an individual obsession. It was, rather, to instruct: to teach his fellow Englishmen that the Italianate model of social behaviour was both superlative and accessible, much as Pace had intended in his far more donnish and self-consciously humanistic - but original - De Fructu. Hoby's introductory epistle states this plainly: he was addressing himself "to young gentlemen, an encouraging to garnish their mind with moral virtues, and their body with comely exercises, and both the one and the other with honest qualities to attain unto their noble end: to ladies and gentlemen, a mirror to deck and trim themselves with virtuous conditions, comely behaviours and honest entertainment toward all men: and to them all in general, a storehouse of most necessary implements for the 
conversation, use, and training up of man's life with courtly demeanors." 31

As with the original, Hoby stressed the moral and virtuous aspects of knighthood, aspects that linked this new style of aristocratic courtly behaviour to the religious and more traditional elements of feudal chivalry, an ideology already well established in the English collective unconscious. His translation, then, was not altogether a new, sharp departure from the practices of the past but rather was a document reinforcing and propagating a movement towards Italianate manners, humanist learning and enlightened moral virtues, based on classical as well as Christian values that had been growing in England from at least the beginning of the century. Hoby's Courtier was a landmark in a process, not an announcement of a revolutionary ideology distinct from the past.

To the extent that the Book of the Courtier made access to the cherished ideals of Castiglione more broadly available than before to the English gentry, the moment was decisive; but as a watershed, a critical point that ushered in a new age animated by new values it is insufficient. The roots of the Italianate nature of Elizabethan culture go far more deeply into the intellectual and cultural traditions that linked the two nations. Hoby's translation of Il Cortegiano might identify a prominent monument in the transformation of the English courtly ideal, but it must not be seen to be the sacred text from which the new confession arose.

\section{University of Toronto}

\section{NOTES}

1 E. Arber, ed., A Transcript of the Registers of the Company of Stationers, London: 1554-1640 (London: Privately printed, 1875), I, p. 155 (f 62).

2 N. Williams, All the Queen's Men (London: Cardinal, 1974), p. 24.

3 Sir Thomas Hoby, trans., The Book of the Courtier of Baldassare Castiglione, ed., W. Raleigh (London: David Nutt, 1900), p. xxvi.

4 J.W. Hebel, H.H. Hudson, et al., eds., Tudor Poetry and Prose (New York: Appleton-Century-Crofts, 1953), p. 1307.

5 J. Buxton, Sir Philip Sidney and the English Renaissance (London: Macmillan, 1954), p. 19.

6 There were ten various editions of The Courtier printed in England during the sixteenth and early seventeenth centuries; see S.T.C. 4778-87. Also, other Italian courtesy books were soon translated, e.g., Il Galateo of Giovanni della Casa, was translated by Robert Peterson in 1576. See S.T.C. 4738.

7 Roger Acham, The Scholemaster, in Giles, ed., Roger Ascham, The Whole Works (London: Bell and Daldy, 1865), iii, p. 141

8 Ascham's violent denunciation of Italy is, of course, famous. This anti-Italianism was continued in the next decade by William Harrison in his Description of England printed in Holinshed's Chronicles (1577). See my "The Strangeness of 
Strangers: English Impressions of Italy in the Sixteenth Century," Quaderni d'italianistica, I.1 (1980), 46-63.

9 Quoted in M. Firpo, Pietro Bizzarri, esule italiano del Cinquecento (Torino: 1971), p. 39 .

10 Ascham disliked the Morte Arthure but not as much as things Italian. He continues in The Scholemaster to note that "And yet the Morte Arthures do not the tenth part so much harm as one of these books made in Italy and translated in England." Hoby's Cortegiano, obviously, is an exception.

11 See R. Weiss, Humanism in England During the Fifteenth Century (Oxford: Blackwell, 1967), p. 39 sqq.

12 Ibid., 109 sqq. Tiptoft arrived in Venice in 1458 and lived after January 1459 in Padua where he may have read law for a short time. He had a wide circle of humanist friends that included Guarino of Verona and his future biographer Vespasiano da Bisticci.

13 Ibid., p. 106 sqq.; p. 97 sqq.; p. 122 sqq.; et passim.

14 For Linacre, Grocyn, Latimer, Tunstall and Pace, see Cardinal Gasquet's Cardinal Pole and his Early Friends (London: Bell, 1927), and G.B. Parks, The English Traveler to Italy (Rome: Edizioni di storia e letteratura, 1954).

15 Richard Pace, De Fructu qui ex doctrina percipitur, ed. and trans., F. Manley and R. Sylvester (New York: Ungar, 1967), p. 23.

16 See C.H. Clough, "The Relations Between the English and Urbino Courts, 1474 - 1508", Studies in the Renaissance, 14 (1967), 202-18.

17 For the household of Pole see W.G. Zeeveld, Foundations of Tudor Policy (Cambridge Mass.: Harvard University Press, 1948).

18 The continuing relationship between Padua and the English Universities was self-sustaining and remarkably fruitful. For a discussion of this connection during the Renaissance, see my "Worshipful Gentlemen of England: The Studio of Padua and the Education of the English Gentry in the Sixteenth Century," Renaissance and Reformation, N.S. 6 (1982), 235-48.

19 Thomas Starkey, A Dialogue Between Pole and Lupset, ed., K. Burton (London: 1948).

20 There were some other translations from the Italian before Wyatt but these did not see print. For example, William Lyly translated, probably as a joke, Il libro della sorte, a book on gaming.

21 M. Dewar, Sir Thomas Smith: A Tudor Intellectual in Office (London: Athlone Press, 1964).

22 The role of the Italian Protestant Church in London was central in disseminating interest in the Italian language and Italian culture. See Frances Yates, John Florio, The Life of an Italian in Shakespeare's London (New York: Octagon, 1968), p. 9. Also individual Englishmen of the highest rank enjoyed private tuition in Italian. The Princess Elizabeth had G.B. Castiglione (no relation to the author of $I l$ Cortegiano) in her household as Italian master, and her cousin Edward Courtenay, although imprisoned in the Tower, wrote a translation of $I l$ Trattato utilissimo del beneficio di Gesú Cristo, a crypto-Protestant tract.

23 Thomas had spent a number of years in Italy and knew Castiglione's Cortegiano in the original, mentioning it in his History of Italy. William Thomas, The Historie of Italie ed., G. B. Parks (Ithaca: Cornell University Press, 1963), p. 127.

24 The best source for Hoby's travels and much of his life is his journal, A Book of the Travaill and Lief of Me Thomas Hoby, ed., E. Powell (London: Camden Society, 1902), This is only a partial text. The complete journal survives in manuscript: B.L. Egerton, 2148.

25 Hoby, Travaill and Lief, p. 78.

26 Ibid., 116.

27 Tamworth (c. 1524-69) was certainly the J.T. to whom Thomas dedicated his book. Later, in addition to enjoying a successful career under Elizabeth, he 
married the sister of Sir Francis Walsingham, another student at Padua during the 1550 's.

28 Hoby, Travaill and Lief, p. 4.

29 Ibid., p. 119.

30 The epitaph on the twin tombs of Sir Thomas Hoby and his brother Sir Philip indicate the esteem in which they were held:

"Two worthye Knightes, and Hobies bothe by name . . .

A courtier passing and a curteis Knight. ..."

Quoted in Hoby, Travaill and Lief, p. xv-xvi.

31 Hoby, trans., Book of the Courtier, p. 7. 